\title{
Exposure to pesticides and digestive system cancers: systematic review and meta-
}

\section{analysis}

Exposição a pesticidas e cânceres do sistema digestivo: revisão sistemática e metanálise

Exposición a pesticidas y cánceres del Sistema digestivo: revisión sistemática y metaanálisis

Received: 08/06/2021 | Reviewed: 08/12/2021 | Accept: 08/18/2021 | Published: 08/21/2021

Iago Sávyo Duarte Santiago

ORCID: https://orcid.org/0000-0002-8707-6846

Federal University of Cariri, Brazil

E-mail: iago.duarte@aluno.ufca.edu.br

Estelita Lima Cândido

ORCID: https://orcid.org/0000-0001-9434-2930

Federal University of Cariri, Brazil

E-mail: estelita.lima@ufca.edu.br

Lucas Farias Lopes

ORCID: https://orcid.org/0000-0001-8112-4723 Federal University of Cariri, Brazil E-mail: lucas.farias@aluno.ufca.edu.br

João Pedro Leite de Medeiros Almeida ORCID: https://orcid.org/0000-0002-0950-5799 Federal University of Cariri, Brazil E-mail: pedro.joao@aluno.ufca.edu.br

Cláudio Gleidiston Lima da Silva ORCID: https://orcid.org/0000-0001-5730-0512 Federal University of Cariri, Brazil E-mail: claudio.gleidiston@ufca.edu.br

\begin{abstract}
Pesticides are substances often described as carcinogenic initiators for some neoplasms, such as lymphohematopoietic and breast cancer. As for cancer of the digestive system, this relationship is still poorly explored and requires more evidence. A systematic review with meta-analysis was conducted on the association between pesticides and cancer of the digestive system in the PUBMED database. Of the 567 papers found, 32 were approved for qualitative analysis and seven for meta-analysis. Hexachlorobenzene and DDT were significantly associated with colorectal cancer (MD: 15.92; CI: 6.45; 25.40) in the analysis of continuous data and showed a borderline association in the analysis of binary data (OR: 1.17 ; CI: $0.93 ; 1.47)$. The cyclodienes family showed similar results in both analyzes. Polychlorinated biphenyls with low dosages were also associated with colorectal cancer (MD: 38.95; CI: 12.78; 65.11). Organophosphates (OR: 0.54; 95\% CI: 0.29; 0.98), carbamates (OR: 0.96; CI: 0.77; 1.21) and triazines (OR: 0.91 ; 95\% CI: 0.74 ; 1.13) showed inconclusive results. This review presents positive evidence for the association of pesticides with colorectal cancer. However, more evidence is required to determine the role of pesticides in the development of other cancers of the digestive system.
\end{abstract}

Keywords: Insecticides; Gastrointestinal Neoplasm; Colorectal Neoplasms; Pesticide Exposure; Agrochemicals.

\section{Resumo}

Os pesticidas são substâncias frequentemente descritas como iniciadores carcinogênicos para algumas neoplasias, como linfo-hematopoiéticas e mamárias. Quanto ao câncer do sistema digestivo, essa relação ainda é pouco explorada e exige maior busca de evidências. Realizou-se uma revisão sistemática com metanálise sobre a associação entre pesticidas e câncer do sistema digestivo na base de dados PUBMED. Dos 567 artigos encontrados, 32 foram aprovados para a análise qualitativa e sete, para a metanálise. Hexaclorobenzeno e DDT estavam significativamente associados ao câncer colorretal (MD: 15.92; CI: 6.45; 25.40) na análise de dados contínuos e apresentaram associação limítrofe na análise de dados binários (OR: 1.17; CI: 0.93; 1.47). A família dos ciclodienos apresentou resultados semelhantes em ambas análises. Os bifenil policlorinados com baixas dosagens também apresentaram associação ao câncer colorretal (MD: 38.95; CI: 12.78; 65.11). Já organofosforados (OR: 0.54; 95\% CI: 0.29; 0.98), carbamatos (OR: 0.96 ; CI: $0.77 ; 1.21$ ) e triazinas (OR: 0.91; 95\% CI: 0.74; 1.13) apresentaram resultados inconclusivos. Esta revisão apresenta evidências positivas da associação de pesticidas ao câncer colorretal. Porém, mais evidências são requeridas para determinar o papel dos pesticidas no desenvolvimento de outros cânceres do sistema digestivo. 
Palavras-chave: Inseticidas; Neoplasias Gastrointestinais; Neoplasias Colorretais; Exposição a Praguicidas; Agroquímicos.

\begin{abstract}
Resumen
Los pesticidas son sustancias frecuentemente descritas como iniciadoras carcinogénicas para algunas neoplasias, como linfohematopoeticas y mamárias. Cuanto al cáncer del sistema digestivo, esa relación aún es poco explorada y exige mayor búsqueda de evidencias. Se realizó uma revisión sistemática com metaanálisis sobre la asociación entre pesticidas y cánceres del sistema digestivo en la base de datos PUBMED. De los 567 artículos encontrados, 32 fueron aprobados para el análisis cualitativo e siete, para la metaanálisis. Hexaclorobenzeno e DDT estaban asociados significativamente al cáncer colorrectal (MD: 15.92; CI: 6.45; 25.40) en el análisis de datos contínuos y presentaron asociación limítrofe en el análisis de datos binários (OR: 1.17; CI: 0.93; 1.47). La familia de los ciclodienos presentó resultados semejantes en ambos análisis. Los bifenil policlorinados con bajas dosis también presentaron asociación al cáncer colorrectal (MD: 38.95; CI: 12.78; 65.11). Los organofosforados (OR: 0.54; 95\% CI: 0.29; 0.98), carbamatos (OR: 0.96; CI: $0.77 ; 1.21)$ y triazinas (OR: 0.91; 95\% CI: 0.74; 1.13) presentaron resultados inconclusivos. Esta revisión presenta evidencias positivas de la asociación de pesticidas al cáncer colorrectal. Sin embargo, más evidencias son requeridas para determinar el papel de los pesticidas en el desarrollo de otros cánceres del sistema digestivo.
\end{abstract}

Palabras clave: Insecticidas; Neoplasias Gastrointestinales; Neoplasias Colorrectales; Exposición a Plaguicidas; Agroquímicos.

\title{
1. Introduction
}

The gastrointestinal system (GIT) - composed of organs such as the esophagus, stomach, small intestine, large intestine and rectum and some glands attached to it, such as pancreas and liver - comprises important sites of cancer involvement, which cause different symptoms to patients in view of the morphological and functional richness of its tissues (Nagtegaal, 2019; Kwekkeboom, 2016). Each organ affected by a type of cancer has a specific pathophysiology, with the interaction between endogenous and environmental factors guiding carcinogenesis and promoting oncogenic activation associated with the pathology (Porth, 2009). Tobacco, alcohol and a low fiber diet are exogenous risk factors associated with different types of cancer in the tract. From this perspective, pesticides enter the list of probable cancer-initiating substances in the gastrointestinal system.

Pesticide is a common term for different classes of insecticides, herbicides, fungicides and other disinfectant chemicals used to kill or protect against pests, which differ in chemical and physical properties between existing classes. Several and different classifications are used to group the compounds. The classification based on the chemical composition of pesticides divides insecticides into organochlorines, organophosphates, carbamates and synthetic pyrethroids, among others (Yadav and Devi, 2017). Fungicides are classified as aliphatic nitrogen, aromatic, etc., while rodenticides are classified as inorganic or organic. Herbicides are divided into anilides, phenoxyacetic, quaternary ammonium, triazines, among others (Akashe et al, 2018). Some are natural compounds, while others comprise a range of varied synthetic compounds or selected types, which can act on organisms that fight for death or for the alteration of growth or behavior (Casida and Durkin, 2016).

Due to their diverse nature and multiple chemical properties, pesticides also have harmful effects on humans, both in the exposure during the application of the products and in the consumption of the foods they treat. The toxic effects range from endocrinological and metabolic disorders to carcinogenesis in some sites, varying the affected site according to the compound (Katzung et al, 2018). Organizations and institutions have already described relationships between pesticides and human pathologies (IARC, 2020a; USEPA, 2013), with some malignant neoplasms, such as hematopoietic, glandular and bladder, strongly associated with them (Kim et al, 2017). However, the relationship between pesticide exposure and cancers of the gastrointestinal system still requires more evidence to be proven.

Understanding the risk factors for GIT malignant neoplasms, as well as their association with pesticide exposure, is urgent in view of the alarming epidemiology. 2018 data indicate that colorectal cancer was the fourth most common cancer 
worldwide, in both sexes and at all ages. Among the ten most common cancers in that year, three belonged to the tract (colorectal, stomach and liver). The analysis by sex reveals that colorectal cancer takes the third position among men, followed by stomach and liver; esophagus falls in seventh position. Among women, colorectal cancer takes second place. In 2018, colorectal cancer was the second cancer with the highest mortality; among the ten most lethal are stomach, liver, esophagus and pancreas. (IARC, 2020b).

Thus, the present study aims to conduct a systematic review with meta-analysis on the association between pesticides and esophageal, gastric, intestinal, colorectal, pancreatic and liver cancers.

\section{Methodology}

\subsection{Question formulation and search strategy}

The present study is a systematic review with meta-analysis (Brasil, 2014), having followed the PRISMA protocol in its design and execution (Liberati et al, 2009). The systematic review considered the PICO strategy, adapted to replace intervention by exposure, for the construction of the review question. We investigated (P) people with some type of cancer in some organs of the GIT (esophagus, stomach and intestine) and some attached glands (pancreas and liver), (I) exposed to pesticides and $(\mathrm{C})$ not exposed, with $(\mathrm{O})$ arithmetic or geometric means of serum or lipid concentration or proportion of people with cancer and exposed and unexposed controls. For this, the PUBMED database was carefully consulted from January 2000 to December 31, 2019 using the descriptors “(esophageal neoplasms OR stomach neoplasms OR intestinal neoplasms OR liver neoplasms OR pancreatic neoplasms) AND (pesticides)", previously consulted in Medical Subject headings (MeSH).

Inclusion criteria Analysis of the studies identified in the database followed judicious and uniform standards and was conducted by three researchers. The following inclusion criteria were used: (1) studies in English, Portuguese or Spanish language, (2) specific methodology (cohorts, case-controls, prevalence or cross-sectional), (3) use of a control group to compare data and (4) human related. Systematic reviews, meta-analyzes, comments and case reports were excluded, as well as studies with insufficient results.

\subsection{Data extraction and quality assessment}

From the selected studies, detailed information was extracted, such as the design, the sample and its size (number of cases and controls, exposed and unexposed), the pesticides used in each study, the organs evaluated, the methodology used and the main results. The papers selected for the systematic review were evaluated in terms of design, methodology used and the complete presentation of the information necessary for quantitative evaluation.

The methodological quality of the studies selected in the review was analyzed using the Newcastle Ottawa Scale (NOS) (Peterson et al, 2011). Based on this instrument, studies are evaluated in 3 main components: selection, comparability and exposure. In the first aspect, the validation of cases, the representativeness of cases, the selection of controls and the definition of controls are observed. Regarding "comparability", it is observed whether control and exposed groups are adjusted for analysis according to the variables considered (for example, age, weight, etc.). Finally, "exposure" analyzes the determination of exposure, the use of the same methods for control and exposed groups and the non-response rate. Each aspect can receive at most one point, with the exception of the topic "comparability", which can receive two. In our assessment, the topic that scored nothing, received no points. The individual evaluation of papers can receive a maximum of nine points. For cross-sectional studies, an adapted NOS scale was used, as idealized by Modesti et al. (2016). It analyzes the same aspects as the original scale, with the addition of a topic under selection, with a maximum score of 10 points. 
The process of searching and analyzing the texts is shown in Figure 1 and the qualitative analysis of the papers included in this study is summarized in the Supplementary Table 1.

\subsection{Statistical analysis}

The information was compiled in Microsoft Excell version 2013 and all analyzes were performed using Rstudio software version 1.2.5042 (RStudio Team, 2020). Forest plots were used to illustrate the association between exposure to pesticides and the occurrence of esophageal, gastric, intestinal, pancreatic or liver cancers. The Higgins index $\left(\mathrm{I}^{2}\right)$ was used to assess the magnitude of statistical heterogeneity. The random effects model was adopted in the meta-analysis to provide a summary effect size that represents the average effect distribution of the selected studies. The choice of the effects model according to the result of $\mathrm{I}^{2}$ has been discouraged considering that the decision of the effects model used must start from the understanding that the included studies do not share the same effect size, and not the result of statistical tests (Borenstein et al,

2011). Continuous data were evaluated according to the main difference (MD), while binary data were shown as Odds Rates (OR).

\section{Results}

\subsection{Selection of studies and characteristics}

The search through the combination of terms in the PUBMED database identified 567 studies. Based on the reading of the titles and abstracts, 66 papers were selected for full evaluation. Of these, from careful and detailed analysis, seven papers were excluded as the presented methodology was not consistent with the review, 23 because they did not have a control group and four because of insufficient results, resulting in 32 studies for systematic review. Seven studies presented the necessary data for the meta-analysis (Figure 1).

Of the 32 selected papers, 21 case-control studies, nine cohorts and two cross-sectional studies related to the theme were identified. Eleven studies investigated the association of GIT organ cancers with exposure to organochlorines (Abdallah et al, 2017; Abolhassani et al, 2019; Hardell et al, 2007; Lee et al, 2018; Louis et al, 2017; McGlynn et al, 2006; Pavuk et al, 2004; Persson et al, 2012; Porru et al, 2001; Safi, 2002; Zhao et al, 2012); seven evaluated the carcinogenic action of various classes of pesticides (such as organochlorines, organophosphates and carbamates, etc.) (Andreotti et al, 2009; Ezzat et al, 2005; Fritschi et al, 2015; Lee et al, 2004; Lee et al, 2007; Mills and Yang, 2007; VoPham et al, 2015); some have evaluated specific pesticides, such as bromomethane (Barry et al, 2012), Imazetaphyr (Koutros et al, 2009), Metalochlor (Rusiecki et al, 2006; Silver et al, 2015) and Acetalohchlor (Lerro et al, 2015). Finally, nine studies analyzed the association of exposure to unspecified pesticides (Antwi et al, 2015; Lo et al, 2007; Lo et al, 2010; Jansson et al, 2006; Kachuri et al, 2017; Meyer et al, 2011; Santibanez et al, 2010; Santibanez et al, 2012; Wang et al, 2002). 
Figure 1 - Flow diagram of the study selection process.

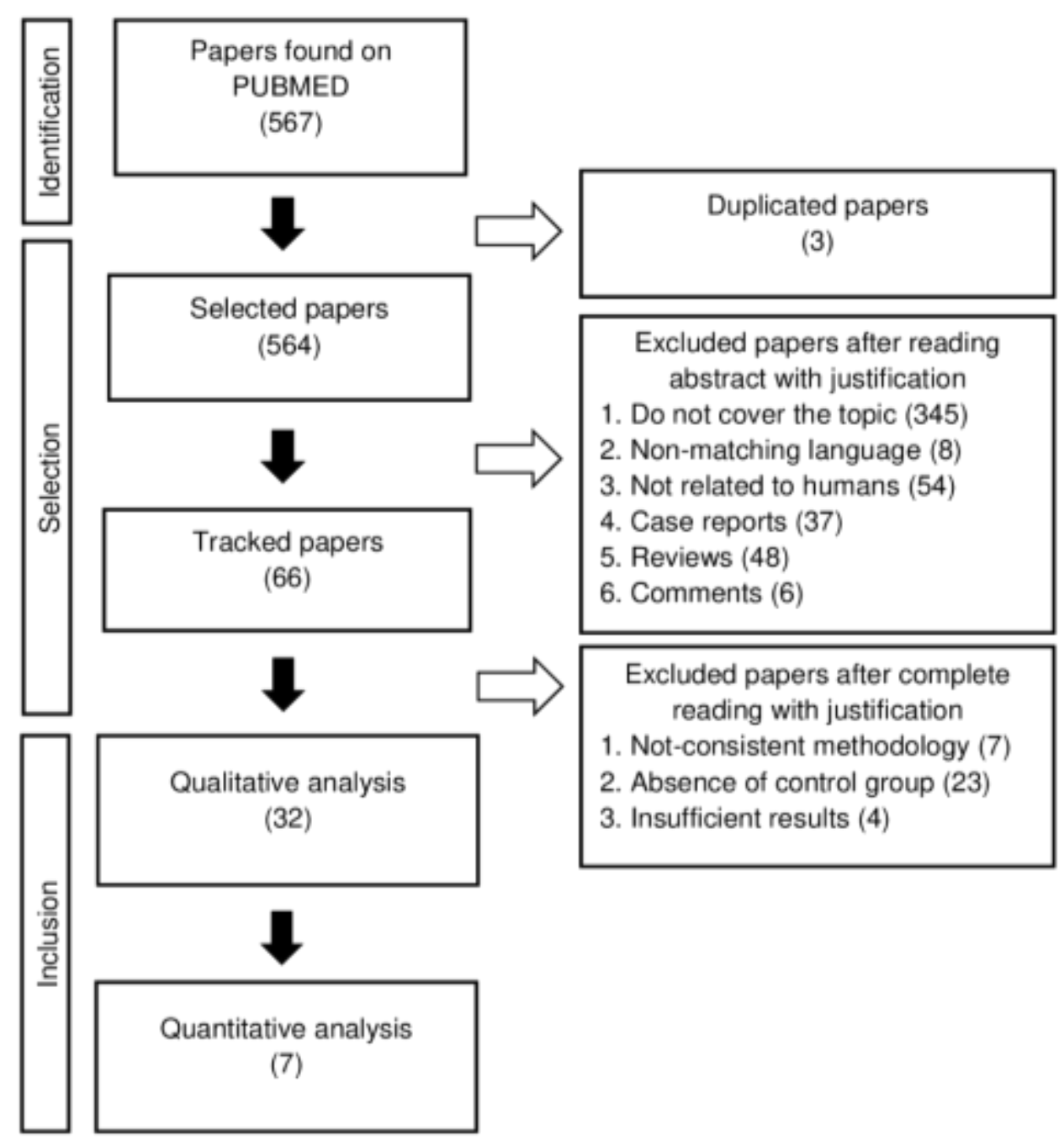

Application of the inclusion and exclusion criteria in the articles found through the PUBMED database resulting in 32 articles for the qualitative assessment and seven for the quantitative analysis.

Source: Authors.

Among the studies that presented the number of participants, the number of cases in the samples of the studies included in the review ranged from 21 to 5,776 people, while the controls ranged from 20 to 56,508 people. The method of investigation of the results most commonly adopted was through the application of questionnaires and / or interviews with exposed and unexposed individuals, evaluating the substances used, the time of use and the form of exposure (labor, domestic, urban, etc. .). Others analyzed the serum concentration of some substances among study participants, while some authors used secondary data extracted from government agencies or hospitals to describe the carcinogenic relationship. Many of these studies (16) have been conducted in American countries, but there are also studies from Asia (8) and European countries (6), in addition to Africa (6) and Oceania (2) in smaller numbers. Supplementary Table 1 presents the characteristics of each study.

\subsection{Evaluation of the quality of the review}

The quality assessment according to NOS revealed that the studies included ranged from five to nine points. Nine studies scored maximum (09 points) and five studies scored 08 points. Ten studies scored 07 points and seven studies scored 
Research, Society and Development, v. 10, n. 11, e06101119163, 2021

(CC BY 4.0) | ISSN 2525-3409 | DOI: http://dx.doi.org/10.33448/rsd-v10i11.19163

06 points. Only one paper scored 05 points. The studies were adjusted for a variety of different confounding factors, the most common being age and sex. All articles presented at least 3 points in the "Selection" criterion. Only two articles collected one point in the "Comparability" criterion, while three did not score at all. The "Exposure" criterion showed the greatest variability of results, ranging from one to three points. Figure 2 shows the result of the classification according to the New Castle Otawa Scalle of the selected papers.

Figure 2 - Classification of papers according to New Castle Ottawa. The papers were evaluated on three topics: selection, comparability and exposure.

Source: Authors.

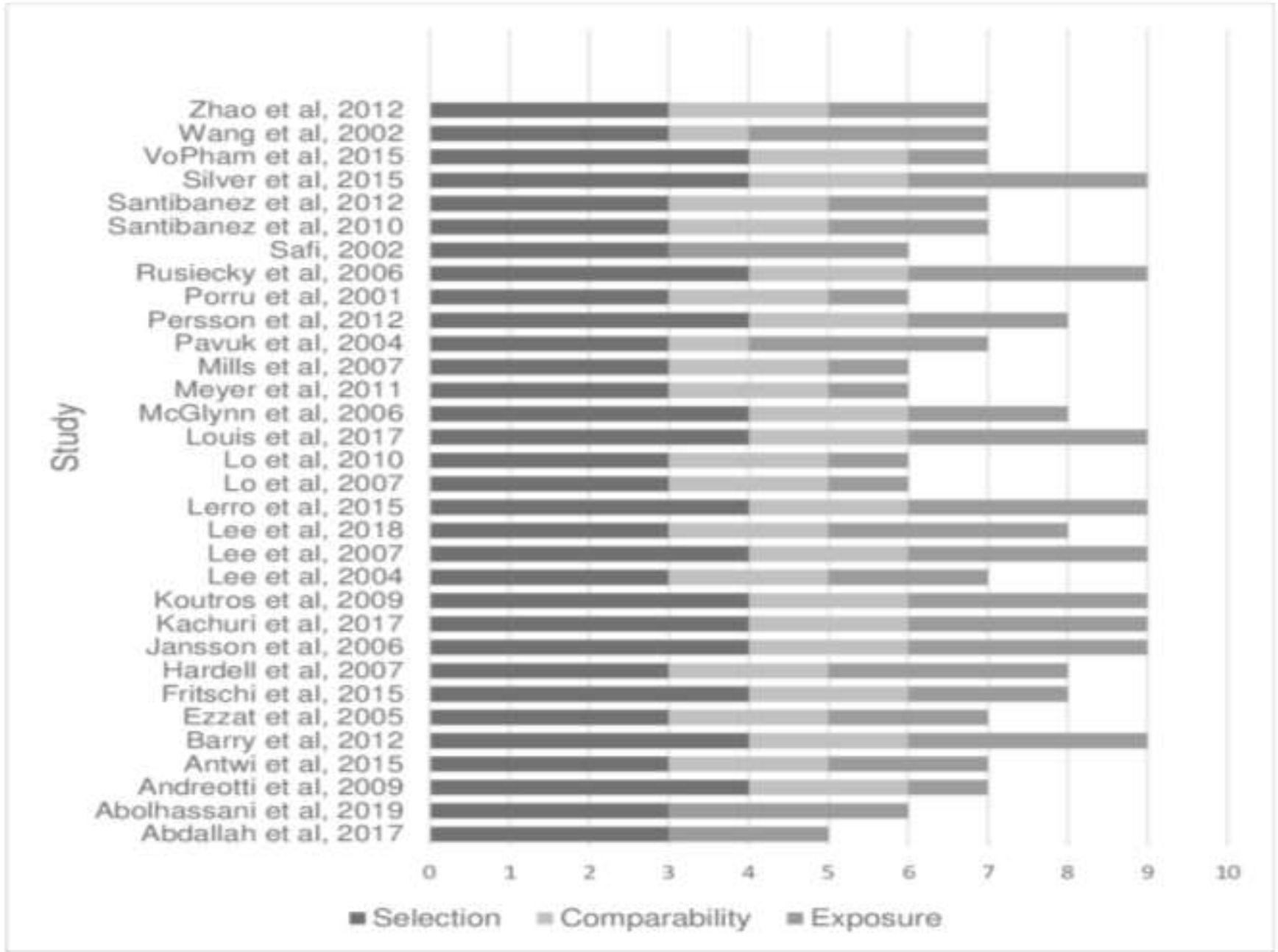

Results of the quality analysis of the 32 articles included in the review, revealing that most articles were methodologically adequate. Source: Authors.

\subsection{Meta-analysis}

The variety of information presented by the studies, with different forms of statistical presentation of the results and the omission of certain important data for the quantitative evaluation of the research, constituted an obstacle to the grouping of the results. Thus, seven studies were selected for the meta-analysis (Abdallah et al, 2017; Abolhassani et al, 2019; Andreotti et al, 2009; Lee et al, 2004; Lee et al, 2018; Mills and Yang, 2007; Zhao et al , 2012) for presenting sufficient data, complete and subject to metanalytical reading. The 42 types of pesticides identified in the included studies presented information 
corresponding to four groups: organochlorines, organophosphates, carbamates and triazines. Among the organochlorines, the family of cyclodienes and polychlorinated biphenyls (PCBs) was individually analyzed.

In the seven papers selected for the meta-analysis, 1021 cases of malignant neoplasms and 84,314 controls in total were evaluated. The meta-analyzes showed different values of $\mathrm{I}^{2}$ in the evaluation of statistical heterogeneity. Even so, the randomized effects model was adopted due to the clinical heterogeneity present in the selected studies, as the samples used in the included studies had different stages of cancer, age and sex and other variables that contribute to the clinical heterogeneity between the studies. The possible presence of methodological heterogeneity is also mentioned in the review. The scarcity of similar data prevented the analysis of heterogeneity by subgroups in the ostensible majority of meta-analyzes. In Figure 3 , the results of meta-analyzes related to organochlorines are described.

The meta-analysis of the pesticides present in the study by Abolhassani et al. (2019), whose data presented the arithmetic mean of the serum concentration of three compounds of the hexachlorocyclohexane (HCH) family, dichlorodiphenyl-trichloroethane (2,4-DDT), an isomer and its metabolites in exposed and non-exposed individuals, revealed that all seven investigated pesticides increase the risk of colorectal cancer (MD: 15.92; 95\% CI: 6.45; 25.40), with $\mathrm{I}^{2}=99 \%$. 4.4 DDT, 2.4 DDT and 4.4 DDE showed the highest MD values (Figure 3.1).

Contrarily, the analysis of data from Lee et al. (2004) and Zhao et al. (2012) (Figure 3.2, subgroup = DDT and HCH) reveal the absence of the relationship between exposure to $\mathrm{HCH}$ and DDT and the development of cancers in the GIT (OR: 1.17 ; $95 \%$ CI: $0.94 ; 1.47)$, with statistical homogeneity $\left(I^{2}=0 \%\right)$. Here, the association between beta-HCH, DDT, $p, \mathrm{p}^{\prime}-\mathrm{DDT}$, $\mathrm{p}, \mathrm{p}^{\prime}$-DDE and hepatocellular carcinoma, gastric and esophageal cancer were analyzed. None of the analyzed pesticides showed a significant association. The adoption of the random effects model revealed beta-HCH, p, $\mathrm{p}^{\prime}$-DDT and DDT with the highest weights.

In relation to the cyclodienes family, the analysis of the binary data of Aldrin and Dieldrin, present in the studies by Lee et al. (2004) and Zhao et al. (2012) showed no evidence of an increased risk of cancer in TGI organs (OR: 0.90; 95\% CI: 0.61; 1.34). Only the data referring to Aldrin, extracted from Zhao et al. (2012) revealed a significant association (Figure 3.2, group = cyclodienes). Differently, the data extracted from Lee et al. (2018) showed a significant relationship (MD = 1070; $95 \% \mathrm{CI}=889.57 ; 1250.80$ ) between the occurrence of colorectal cancer and exposure to pesticides, with $\mathrm{I}^{2}=100 \%$ and application of the random effects model (Figure 3.3). All pesticides analyzed showed a significant relationship between the association. The highest MDs were registered by oxychlordane, trans-nonachlor and heptachlor epoxide. Trans-chlordane, heptachlor and cis-nonachlor had the highest weights (17.9\%, 17.9\% and $17.7 \%$, respectively). 
Figure 3 - Meta-analysis of organochlorine pesticides.

\section{1 - HCH and DDT}

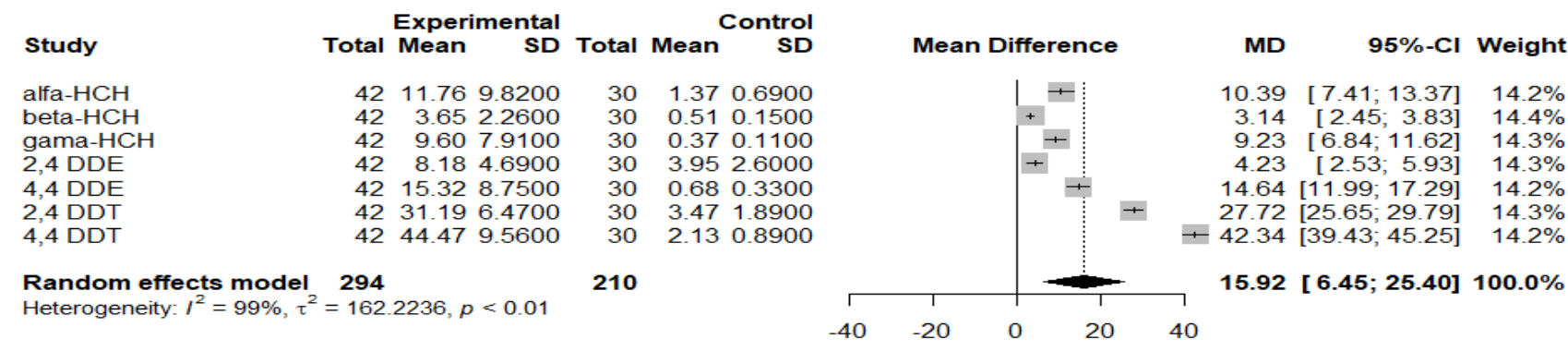

\section{2 - Organochlorines}

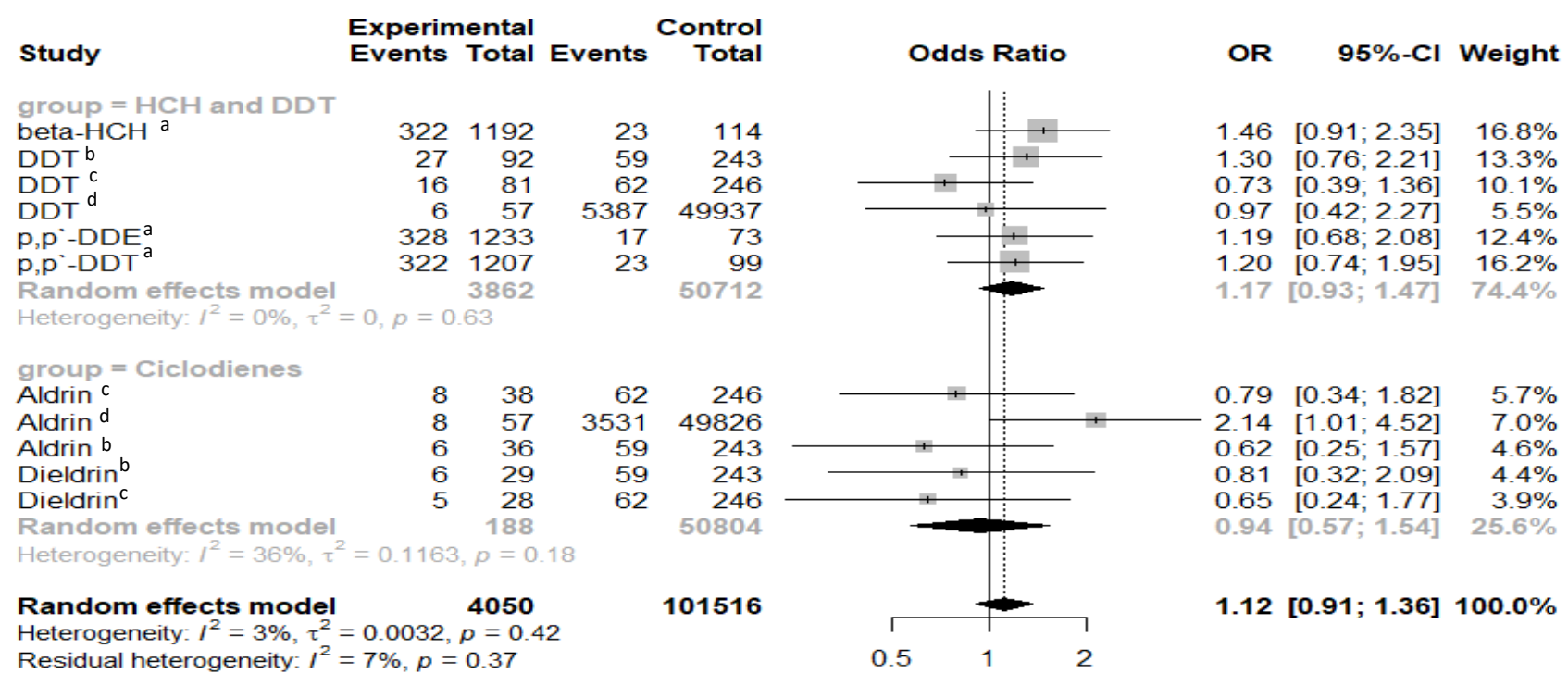

\section{3 - Cyclodiene}

\begin{tabular}{|c|c|c|c|c|c|c|}
\hline \multirow[b]{2}{*}{ Study } & \multirow[b]{2}{*}{ Total } & \multicolumn{2}{|c|}{ Experimental } & \multirow[b]{2}{*}{ Total } & \multicolumn{2}{|c|}{ Control } \\
\hline & & Mean & SD & & Mean & \\
\hline trans-chlordane & 99 & 100.10 & 10.6000 & 76 & 90.90 & 10.6000 \\
\hline ordane & 99 & 4079.30 & 807.3000 & 76 & 750.90 & 163.2000 \\
\hline trans-nonachlor & 99 & 7612.30 & 877.4000 & 76 & 5902.40 & 747.2000 \\
\hline cis-nonachlor & 99 & 738.20 & 143.1000 & 76 & 556.30 & 118.5000 \\
\hline heptachlor epoxide & 99 & 2179.20 & 366.9000 & 76 & 609.40 & 112.7000 \\
\hline heptachlor & 99 & 260.60 & 38.0000 & 76 & 188.70 & 30.2000 \\
\hline $\begin{array}{l}\text { Random effects model } \\
\text { Heterogeneity: } I^{2}=100 \%, \tau^{2}\end{array}$ & $\begin{array}{l}594 \\
t^{2}=474\end{array}$ & 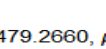 & & 456 & & \\
\hline
\end{tabular}

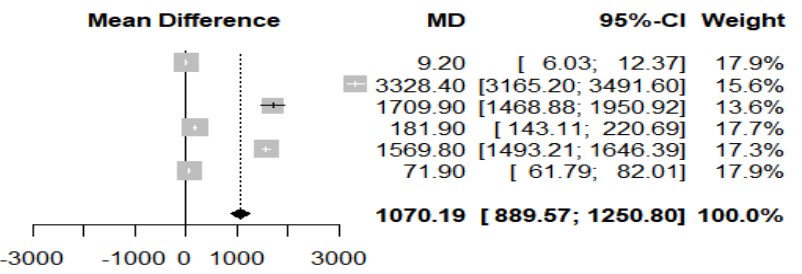

$\mathrm{a}=$ Zhao et al, 2012; b = Lee et al, 2004 (gastric cancer); c = Lee et al, 2004 (esophageal cancer); d = Andreotti et al, 2009

Source: Authors.

Evaluation of organochlorine pesticides showing different results according to the analyzed site and the considered variable. 3.1) $\mathrm{HCH}$ and DDT showing MD of 15.92 [6.45; 25.40], with all pesticides showing association with colorectal cancer 3.2) Evaluation of $\mathrm{HCH}$ and DDT in binary data revealing OR 1.17 [0.93; 1.47]. Non-significant result also for the binary data of the cyclodienes 3.3) Analysis of the continuous data of the cyclodienes showing MD 1070.19 [889.57; 1250.80].

Lee et al. (2018) and Abdallah et al. (2017) presented data on different types of polychlorinated biphenyls (PCBs). While the former's analysis observed the geometric mean of the pesticide's lipid accumulation in ng / g of lipid (with values ranging between 81.40 and $21956.70 \mathrm{ng} / \mathrm{g}$ ) in patients with colorectal cancer, the latter presented its results from the arithmetic mean of the concentration serum levels of pesticides. Thus, it was not possible to group the different data in a single analysis. In Figure 4.1, the data extracted from Lee et al. (2018) referring to 8 PCBs $(18,28,33,52,101,105,194$, 199) with a 
lipid concentration below $2000 \mathrm{ng} / \mathrm{g}$ of lipid, revealing a positive association between exposure to PCBs and the development of GIT neoplasms (MD 38.95; 95\% CI $=12.78 ; 65.11$ ), with index $\mathrm{I}^{2}=99 \%$. The individual analysis of pesticides reveals significance between PCBs 18, 33, 52, 101 and 199.

Figure 4.2 gathers the pesticides PCB 118, PCB 138, PCB 153, PCB 170, PCB 180 and PCB 187 with a concentration greater than $2000 \mathrm{ng} / \mathrm{g}$ of lipid in the studies by Lee et al 2018. The analysis showed no evidence in the association (MD = 1128.34; 95\% CI $=-2392.87 ; 136.19)$, with high heterogeneity $\left(I^{2}=100 \%\right)$. PCB 170 and PCB 180 showed a significant positive correlation, while PCB 138 and PCB 153 showed an inverse association. The lack of significance of PCBs 118, 138, 153, 170 and 180 was also observed in the data extracted from Abdallah et al. (2017) $(\mathrm{MD}=0.08 ; 95 \% \mathrm{CI}=-0.17 ; 0.33)$, with no statistical heterogeneity $\left(\mathrm{I}^{2}=0 \%\right)$. In this, none of the analyzed pesticides showed a significant association (Figure 4.3).

Figure 4 - Meta-analysis of polycholinated biphenyl (PCB).

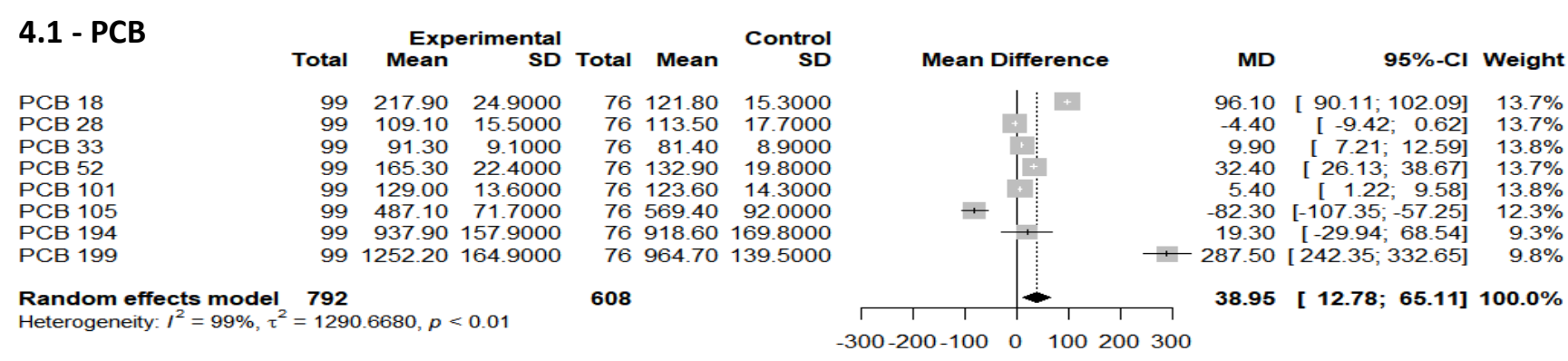

$4.2-$ PCB

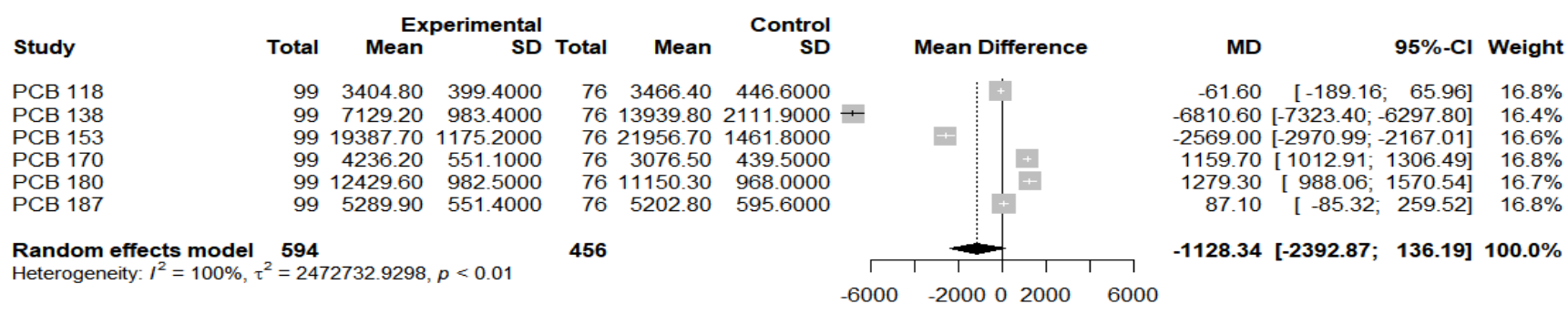

\section{3 - PCB}

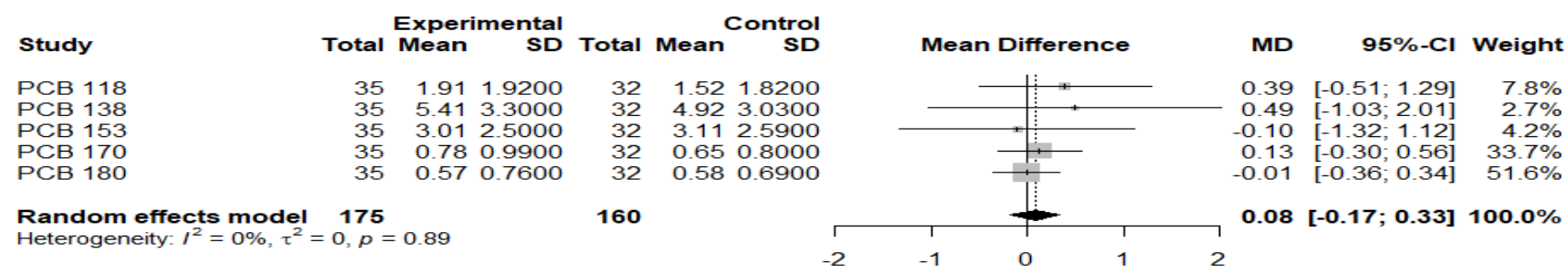

PCBs showing different evidence for carcinogenic association. 4.1) PCBs with lipid concentration below $2000 \mathrm{ng} / \mathrm{g}$ presenting MD 38.95 [12.78; 65.11] 4.2) PCBs with concentration superior to $2000 \mathrm{ng} / \mathrm{g}$ revealing inconclusive association 4.3) Analysis of binary data of PCBs with concentration superior to $2000 \mathrm{ng} / \mathrm{g}$ showing MD 0.08 [-0.17;0.33].

Source: Authors.

Figure 5 shows data on the analysis of organophosphates. The data extracted from Mills and Yang (2007), Lee et al. (2004) and Andreotti et al. (2009) presented an inconclusive result regarding exposure to organophosphates and the organs analyzed (OR: $0.86 ; 95 \%$ CI: $0.69 ; 1.08)$. The individual analysis of the pesticides shows that none was significantly associated with an increased risk of cancer. Malathion (OR: 0.54; 95\% CI: 0.29; 0.98) showed an inverse association. The highest weights were presented by Terbufos (12.0\%) and Chlorpyrifos (10.2\%). 
Figure 5 - Meta-analysis of organophosphates.

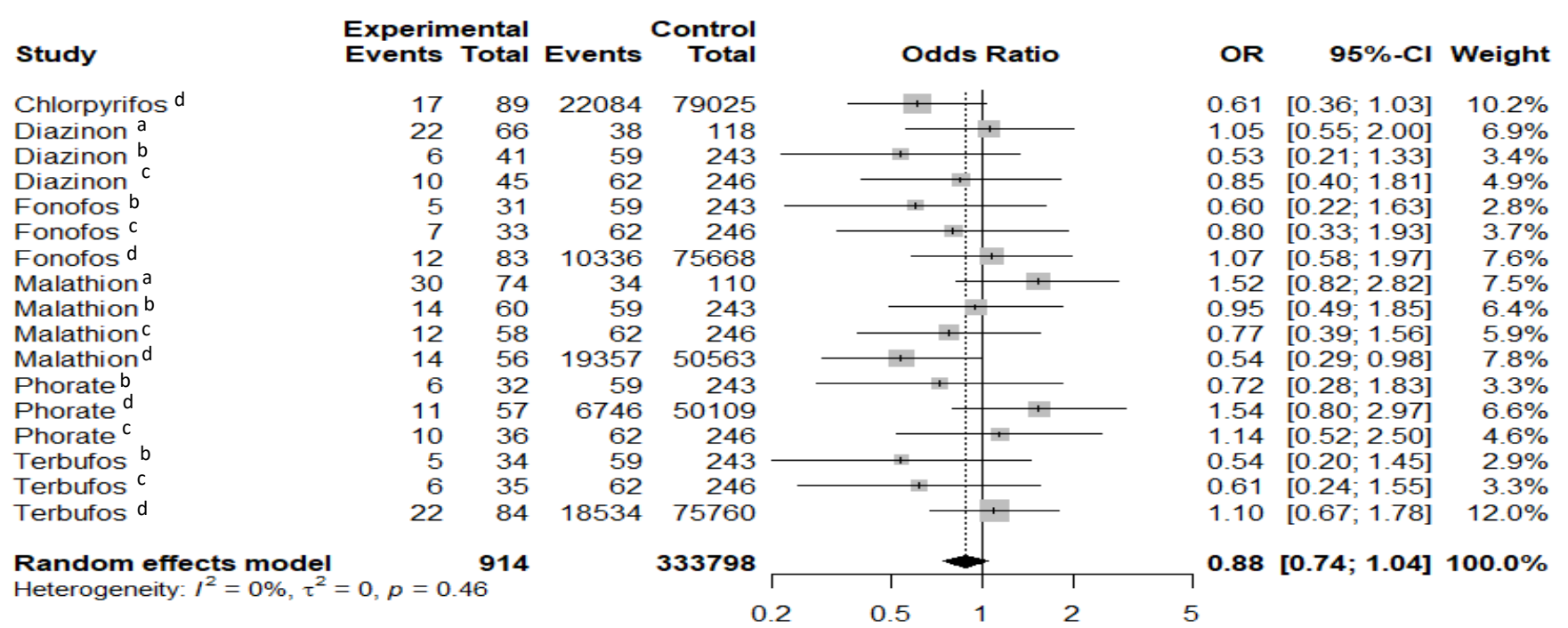

a= Mills and Yang, 2007; b= Lee et al, 2004 (gastric cancer); c= Lee et al, 2004 (esophageal cancer); d= Andreotti et al, 2009

Organophosphates showing inconclusive results regarding the association with GIT cancers, with OR 0.88 [0.74; 1.04 ]. Source: Authors.

The carbamate analysis included four distinct compounds from Mills and Yang (2007) and Lee et al. (2004) and presented an inconclusive result both in the total result and in the individual analysis of the pesticides (OR: 0.96; CI: 0.77; 1.21) (Figure 6.1). The adoption of the random model showed greater weights for Carbaryl (18.6\%) and Carbofuran (14.9\%). Finally, Lee et al. (2004) and Andreotti et al. (2009) presented data on exposure to triazines and the occurrence of cancers located in three different sites, with non-conclusive results (OR: $0.91 ; 95 \% \mathrm{CI}: 0.74 ; 1.13)$ and statistical homogeneity $\left(\mathrm{I}^{2}=0\right)$. All the pesticides analyzed showed no significant result (Figure 6.2). 
Figure 6 - Meta-analysis of carbamates and Triazines.

\section{1 - Carbamates}

\begin{tabular}{|c|c|}
\hline Study & $\begin{array}{l}\text { Experim } \\
\text { Events }\end{array}$ \\
\hline Carbaryl $^{\text {b }}$ & 9 \\
\hline Carbaryl ${ }^{\mathrm{C}}$ & 12 \\
\hline Carbaryl $^{d}$ & 17 \\
\hline Carbofuran ${ }^{b}$ & 9 \\
\hline Carbofuran c & 11 \\
\hline Carbofuran d & 14 \\
\hline Mancozeb ${ }^{a}$ & 26 \\
\hline Maneb a & 28 \\
\hline
\end{tabular}

\section{2 - Triazines}

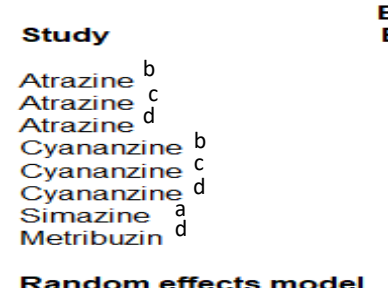

Random effects model
Control

Total

$\begin{array}{rr}59 & 243 \\ 62 & 246 \\ 18197 & 50686 \\ 59 & 243 \\ 62 & 246 \\ 12756 & 75352 \\ 55 & 165 \\ 54 & 152\end{array}$

127333

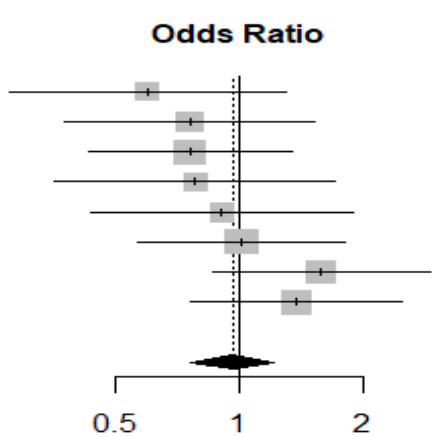

0.5

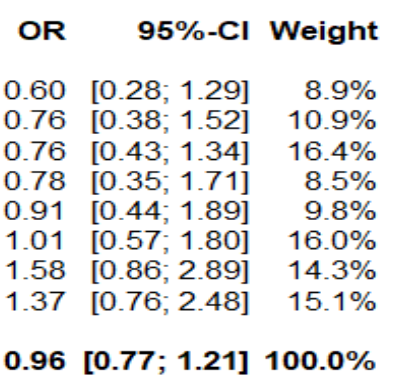

$0.96[0.77 ; 1.21] 100.0 \%$

$a=$ Mills and Yang, 2007; b= Lee et al, 2004 (gastric cancer); c= Lee et al, 2004 (esophageal cancer); d= Andreotti et al, 2009

Carbamates and triazines showing inconclusive results in the assessment of their exposure and GIT cancers. 6.1) Carbamates with OR 0.96 [0.77;1.21] 6.2) Triazines showing OR $0.91[0.74 ; 1.13]$.

Source: Authors.

\section{Discussion}

Due to the progression of the number of cases of cancers located in the gastrointestinal tract (IARC, 2020b), it is necessary to understand the associated factors to design strategies for prevention and early detection. Our meta-analysis was conducted to help elucidate the issue related to the increased risk of malignant neoplasms through exposure to pesticides. All studies present in the consulted database that discussed the association between exposure to pesticides and carcinogenic initiation in the esophagus, stomach, intestine, pancreas and liver were reviewed. The results of the present study bring different conclusions about the variety of pesticides investigated.

Some studies in the review evaluated the increased risk of cancer and exposure to pesticides, without specifying the compounds. Pesticides have been associated with possible carcinogenic effects in colorectal (Lo et al, 2010) and pancreatic (Antwin et al, 2015; Meyer et al, 2011) cancers. Other studies have assessed the significant association with ductal adenomacarcinoma and gastric cardiac adenocarcinoma only in individuals with high exposure (Santibanez et al, 2012; Jansson et al, 2006). Occupational exposure in the field was also assessed as a factor that increases the risk of pancreatic cancer (Santibanez et al, 2010), as well as there was a significant increase in the same cancer among farmers who frequently consumed the products grown on their own farms (Lo et al 2007). On the other hand, a study demonstrated a lack of relationship between exposure to pesticides and cancers of the colon, rectum, stomach, pancreas and esophagus (Kachuri et al 2017), as well as a non-significant incidence among women farmers and colorectal and liver cancer (Wang et al, 2002).

Some authors have analyzed compounds belonging to other groups and have shown different associations. Methyl bromide was associated with an increased risk of stomach cancer (Barry et al, 2012), acetalochlor showed significant results with liver cancer and borderline in relation to pancreatic cancer (Lerro et al, 2015), while imazetaphyr showed increased risk of 
proximal colon cancer (Koutros et al, 2009). The investigation of metalochlor demonstrated some association with liver cancer (Silver et al, 2015) and the absence of a significant result with colon cancer (Rusiecki et al, 2006).

Organochlorines are considered persistent chemical agents, with slow degradation and well-documented bioaccumulation. Despite the banning in several countries, the long-term effects have not yet been fully elucidated (Katzung et al, 2018). The dubiousness regarding the results of HCH and DDT can be justified by the clinical heterogeneity present in the studies, influenced here by the different oncological sites and by the different staging of the cases analyzed, in addition to the different levels and quality of exposure of the agents, which generates discordant results. The association is positive in the analysis of colorectal cancer and inconclusive when comparing data on esophageal, gastric, pancreatic and liver cancers. The analysis of such inconclusiveness must consider the extent of the confidence interval and the borderline result for the relationship (Brasil, 2012).

The dubiousness of the relationship also present in the results referring to the family of cyclodienes should be analyzed according to the same critical aspects, since the global inconclusive result related to binary data, which analyzes esophageal, gastric and pancreatic cancers, presents an even wider confidence interval than the previous group. In the case of colorectal cancer, the relationship is significant.

The IARC classifies DDT and Dieldrin (and its metabolite Aldrin) as probable human carcinogens due to the already known carcinogenic effect in some sites. DDT is associated with liver and bile duct cancer, as well as testicle and leukemia / lymphoma, while exposure to Dieldrin is associated with the occurrence of breast cancer (IARC, 2020a). A recent systematic review evaluated the association between organochlorinated exposure and increased risk of pancreatic cancer. The results suggest some evidence that exposure to high organochlorinated levels may be associated with this cancer, but larger analyses would be required (Andreotti and Silverman, 2011). Other reviews also showed similar results in the association (Bassil et al, 2007; Beard, 2006). However, the results present in an earlier review corroborate our data presented in this paper regarding the dubiousness of the association of pancreatic cancer with organochlorinated, although it suggests some specific evidence of the relationship with DDT (Jaga and Dharmani, 2005). DDT presented the most convincing results among organochlorinated in relation to the association with liver cancer among three revised control cases (Vopham et al, 2017).

In our review, McGlyn et al. (2006) demonstrated increased risk of liver cancer in patients with high serum rates of DDT, while DDE did not show significant results. In the case of hepatocellular carcinoma specifically, both p,p'-DDT and HCC were associated with increased risk (Vopham et al, 2015; Persson et al, 2012). In pancreatic cancer, Fritschi et al. (2015) did not observe a significant association, whereas Hardell et al. (2007) showed significance for exposure to HCB and Louis et al. (2017) showed a significant association only with Lindano. In the analysis of colorectal, colon and rectum cancer, no association was observed with DDT (Lee et al, 2007). In relation to cyclodiene, there was a high risk of colorectal cancer at aldrin exposure, with non-significant findings for dieldrin, chlordane and heptaclor. All these pesticides presented null OR for the occurrence of colon and rectum cancer (Lee et al 2007). In another study, the evaluation of the lipid concentration of clordans among patients with pancreatic cancer and controls demonstrated significance $(\mathrm{P}<0.005)$ for cis-heptachlordane, trans-chlordane, oxychlordane and cis-nonachlordane. Only trans-nonachlordane showed no significant result ( $\mathrm{p}=0.005)$ (Hardell et al, 2007). The diversity and disparity of results accentuates the inconclusion regarding the effective influence of organochlorinated on carcinogenesis.

PCBs are polychlorinated chemical compounds once used on a large scale in various applications. The endocrine destabilization promoted by it and the possible carcinogenic action on some cancers, such as melanoma, breast and pancreas, placed it in a central process of discussion about its banishment (Katzung et al, 2018). Its association with cancers of the gastrointestinal system has not yet been fully elucidated. Our study showed a positive association of compounds with lower 
lipid dosage and colorectal and inconclusion cancer with those with high lipid rate. The latter confirmed by the two analyses undertaken. In both cases, the confidence interval should also be considered for any interpretation.

For IARC, PCBs are human carcinogens (classification 1), with a known association with skin, breast and leukemia/lymphoma cancer (IARC, 2020a). Previous reviews with a small number of studies included reported the association of exposure to PCBs and pancreatic cancer (Zani et al, 2013). In our meta-analysis, some results show no association between exposure to compounds and liver cancer.

The papers included in the systematic review that related PCB and the occurrence of GIT neoplasms support the hypothesis of carcinogenic relationship. Analyzing 21 patients with exocrine pancreatic adenocarcinoma and 59 controls, Hardel et al. (2007) demonstrated that the concentrations of the sum of 35 PCB compounds in $\mathrm{ng} / \mathrm{g}$ of lipid were significant compared to the control $(\mathrm{p}<0.0001)$, with a similar result for the PCB 153 compound alone, whose concentration was the highest in the analysis. Patients with total concentration of PCBs higher than the median concentration of cases presented lower and significant median survival. It is known that the increase in organochlorinated can occur during weight loss, common in the final stage of pancreatic cancer. The analysis of individuals from areas with high and low exposure to PCB showed significant concentration of compounds in men and women, with a small but significant increase in gastric cancer in both sexes and peritoneal, in males, in the most exposed region (Pavuk et al, 2004).

Our meta-analysis showed inconclusive results for the organophosphate and carbamate group. Organophosphates are not persistent pesticides. They are mainly associated with acute effects on the body and their most known long-term effects are some central neuronal changes (Katzung et al, 2018). However, Diazinon and Malathion are likely human carcinogens, associated both with leukemia/lymphoma and the latter also with prostate cancer. Among carbamates, carbaryl and maneb were previously analyzed and described as non-classifiable as carcinogens to humans (IARC, 2020a). The acute toxic effects of carbamates, compared to organophosphates, present clinical signs and symptoms of shorter duration and variation between the dose of mild and lethal intoxication (Katzung et al, 2018).

The information present in the review are multiple and present different results for the issue. Evaluating the association of exposure to organophosphates and increased risk of colorectal cancer, Lee et al. (2007) demonstrated that Chorpyrifos has no significant association with any of the cancers evaluated (colorectal, colorectal and rehest). Similar results were observed for Diazinon, Malathion, Parathion, Phorate and Terbufos. Two pesticides were associated with some type of cancer: toxaphene revealed increased risk for rectal and fonofos cancer for colorectal and colon cancer. The analysis of the relationship with hepatocellular carcinoma also did not show an increased risk of neoplasm (Vopham et al, 2015), as well as the absence of evidence was described for pancreatic cancer (Fritschi et al, 2015). On the other hand, Ezzat et al. (2005) reveals a significant association between liver carcinoma and exposure to organophosphate compounds (organophosphorus fungicides, organothiophosphate insecticides, phospherophenyl amino, phosphate and phosphoramidate).

Our review also presents data on carbamates. A 2015 control case reveals a zero association of carbamates and the risk of hepatocellular carcinoma regardless of the level of exposure to the chemical group (low, moderate and high) (Vopham et al, 2015). Other papers, however, present discordant results. The findings of Ezzat et al. (2005) demonstrate favorable information for the association: both insecticide and acaracid carbamates and the analysis of all carbamate compounds revealed significant results in relation to hepatocellular carcinoma. Lee et al. (2007), in the analysis of exposure to carbaryl and carbofuran, demonstrated that there is only a significant association between carbaryl carbamate and rectal cancer, with no association for colorectal and colon cancer.

The data from our meta-analysis differ from some evidence. A 2017 review concluded that insecticides from organophosphate groups and carbamates have some evidence of association with liver cancer (Vopham et al, 2017). In other 
studies, organophosphates were also related to the risk of increased liver cancer (Jaga and Dharmani, 2005) and colorectal (Alavanja and Bonner, 2012). These results are, however, also inconclusive in view of the existing bias in the reviewed studies and the small number of papers included in each review. Evidence of carcinogenicity was observed by the Canadian Pest Management Regulatory Agency and the U.S. Environmental Protection Agency in animal toxicity studies for some substances, such as cabaril, supporting the biological plausibility of associations derived from these pesticides (Kim et al, 2017).

In relation to triazines, IARC describes atrazine and simazine as non-classifiable to human carcinogens (IARC, 2020a). Evaluations of the group revealed low toxicity for humans, however there are some controversies in this issue, such as its possible involvement in reproductive/endocrine problems, effects on the immune system, among others (Semren et al, 2018). In our review, one study suggested that the association of acetalochlor and atrazine was related to borderline increase in pancreatic risk $(\mathrm{RR}=2.62 ; 95 \% \mathrm{CI}$ : 0.95-7.20) (Lerro et al, 2015). On the other hand, no association of atrazine, cyanazine and metribuzin with colorectal cancer was evidenced (Lee et al 2007).

The present systematic review summarized the data published in the database consulted on the association between malignant neoplasms of some organs of the gastrointestinal tract and exposure to organochlorinated, organophosphates, carbamates and trialine from the combination of different terms, sensitive and specific to the theme. This is the first metaanalysis to analyze the association of so many classes of pesticides with cancers in these organs. The analysis of binary and continuous data and the large number of information inserted configure the main forces of this meta-analysis.

Invariably, our review and meta-analysis presented several limitations. Part of the studies was concentrated in one American country (USA), with irregular distribution in other continents. In Africa, studies focused on Egypt. This distribution may not allow the analysis of different realities regarding pesticide exposure and link the results of meta-analysis to a country/region, with specific characteristics regarding exposure (more or less exposed). It is also mentioned the limited number of studies investigating the association of exposure to pesticides and the occurrence of malignant neoplasms in GIT organs. A much larger number of studies investigate the association between lymphocytic or hematic neoplasms, breast and prostate. The lack of a broad literature on the issue prevented the analysis of the association by organs, requiring the grouping of these as a system. Many of the existing studies on organ cancers investigated in this paper did not present the necessary information for quantitative analysis, limiting the number of studies included in the meta-analysis. In addition, the different forms of data presentation (proportions, geometric mean, arithmetic mean, etc.) and the absence of information pertinent to meta-analysis (such as the non-presentation of the number of cases and/or controls, the number of exposed and/or unexposed individuals or the binary data used in the study) prevented the execution of a single analysis, requiring the separation of the data.

It is important to highlight that the included studies showed variation in methodological quality, an aspect evidenced by the results of the New Castle-Ottawa Scale. Among the papers included in the meta-analyses of binary data, some evaluated the time/degree of exposure of the individual by self-report, without deeper or quantitative analyses of the data. The validity of the scale used (NOS) was questioned by previous studies (Stang, 2010). Other more validated scales were not used here, such as ROBINS-I (Sterne et al, 2016), because they are based on intervention studies, and therefore cannot be applied here because all the studies included were observational.

\section{Conclusion}

In summary, the findings suggest a possible carcinogenic effect of organochlorinated on colorectal cancer, with an association with $\mathrm{HCH}$, DDT and derivatives, cyclodiene sands and some PCBs compounds. The results are borderline to the association of organochlorinated and other cancers. Regarding organophosphates, carbamates and triazines, the data were 
inconclusive. The existence of distinct and multiple information may raise the hypothesis of possible carcinogenic effect, requiring further studies for its confirmation. The interpretation of the information explained here should consider the limitations listed, as well as the magnitude of the confidence intervals in the overall results. An analysis of each organ, with a greater number of studies, could elucidate the question more assertively. Further studies are needed for more concrete conclusions about the relationship between pesticides and esophageal, gastric, intestinal, liver and pancreatic cancers, with methodological adjustments for greater strength of evidence. In this sense, a greater number of studies that assess exposure using a similar methodology, associated with a larger number of studies focused on the same site, may provide stronger evidence on the association between GIT cancers and exposure to pesticides.

\section{Acknowledgments}

We appreciate the help of Ana Paula Tavares, who strongly supported us during the development of this research.

\section{Funding}

This work was supported by the Cearense Foundation for Support for Scientific and Technological Development (FUNCAP), Ceará, Brazil.

\section{References}

Abdallah, M.A.E., Zaky, A.H., \& Covaci, A. (2017). Levels and profiles of organohalogenated contaminants in human blood from Egypt. Chemosphere, 176, 266-272. http://dx.doi.org/10.1016/j.chemosphere.2017.02.139

Abolhassani, M., Asadikaram, G., Paydar, P., Fallah, H., Aghaee-Afshar, M., Moazed, V., Akbari, H., Moghaddam, S.D., \& Moradi, A. (2019). Organochlorine and organophosphorous pesticides may induce colorectal cancer; A case-control study. Ecotoxicology and environmental safety, $178,168-177$. https://doi.org/10.1016/j.ecoenv.2019.04.030

Akashe, M. M., Pawade, U. V., \& Nikam, A. V. (2018). Classification of pesticides: a review. International Journal of Research in Ayurveda and Pharmacy, 9(4), 144-150. doi:10.7897/2277-4343.094131

Alavanja, M. C. R., \& Bonner, M. R. (2012). Occupational Pesticide Exposures and Cancer Risk: A Review. Journal of Toxicology and Environmental Health, Part B, 15(4), 238-263. doi:10.1080/10937404.2012.632358

Andreotti, G., Freeman, L.E.B., Hou, L., Coble, J., Rusiecki, J., Hoppin, J.A., Silverman, D.T., \& Alavanja, M.C.. (2009). Agricultural pesticide use and pancreatic cancer risk in the Agricultural Health Study Cohort. International journal of cancer, 124(10), 2495-2500. https://doi.org/10.1002/ijc.24185

Andreotti, G., \& Silverman, D. T. (2011). Occupational risk factors and pancreatic cancer: A review of recent findings. Molecular Carcinogenesis, 51(1), 98108. doi:10.1002/mc.20779

Antwi, S. O., Eckert, E. C., Sabaque, C. V., Leof, E. R., Hawthorne, K. M., Bamlet, W. R., Chaffee, K .G., Oberg, A. L., \& Petersen, G.M. (2015). Exposure to environmental chemicals and heavy metals, and risk of pancreatic cancer. Cancer Causes \& Control, 26(11), 1583-1591. https://doi.org/10.1007/s10552$015-0652-y$

Bassil, K. L., Vakil, C., Sanborn, M., Cole, D. C., Kaur, J. S., \& Kerr, K. J. (2007). Cancer health effects of pesticides: systematic review. Canadian family physician Medecin de famille canadien, 53(10), 1704-1711.

Barry, K. H., Koutros, S., Lubin, J. H., Coble, J. B., Barone-Adesi, F., Beane Freeman, L. E., Sandler, D. P., Hoppin, J. A., Ma, X., Zheng, T., \& Alavanja, M.C.R. (2012). Methyl bromide exposure and cancer risk in the Agricultural Health Study. Cancer Causes \& Control,23(6), 807-818. https://doi.org/10.1007/s10552-012-9949-2

Beard, J. (2006). DDT and human health. Science of The Total Environment, 355(1-3), 78-89. doi:10.1016/j.scitotenv.2005.02.022

Borenstein, M., Hedges, L. V., Higgins, J. P., \& Rothstein, H. R. (2011). Introduction to meta-analysis. John Wiley \& Sons.

Brasil, Ministério da Saúde (MS), Secretaria de Ciência, Tecnologia e Insumos Estratégicos, \& Departamento de Ciência e Tecnologia (2012). Diretrizes metodológicas: elaboração de revisão sistemática e metanálise de ensaios clínicos randomizados. Brasil.

Brasil, Ministério da Saúde (MS), Secretaria de Ciência, Tecnologia e Insumos Estratégicos, \& Departamento de Ciência e Tecnologia (2014). Diretrizes Metodológicas: elaboração de revisão sistemática de estudos observacionais comparativos sobre fatores de risco e prognóstico. Brasil. 
Casida, J. E., \& Durkin, K. A. (2016). Pesticide Chemical Research in Toxicology: Lessons from Nature. Chemical Research in Toxicology, 30(1), 94104. doi:10.1021/acs.chemrestox.6b00303

Ezzat, S., Abdel-Hamid, M., Eissa, S. A. L., Mokhtar, N., Labib, N. A., El-Ghorory, L., Mikhail, N. N., Abdel-Hamid, A., Hifnawy, T., Strickland, G. T., \& Loffredo, C .A. (2005). Associations of pesticides, HCV, HBV, and hepatocellular carcinoma in Egypt. International journal of hygiene and environmental health, 208(5), 329-339. https://doi.org/10.1016/j.ijheh.2005.04.003

Fritschi, L., Benke, G., Risch, H. A., Schulte, A., Webb, P. M., Whiteman, D.C., Fawcett, J., \& Neale, R.E. (2015). Occupational exposure to N-nitrosamines and pesticides and risk of pancreatic cancer. Occupational and environmental medicine, 72(9), 678-683. http://dx.doi.org/10.1136/oemed-2014-102522

Hardell, L., Carlberg, M., Hardell, K., Björnfoth, H., Wickbom, G., Ionescu, M., Bavel, B. V., \& Lindström, G. (2007). Decreased survival in pancreatic cancer patients with high concentrations of organochlorines in adipose tissue. Biomedicine \& pharmacotherapy,61(10), 659-664. https://doi.org/10.1016/j.biopha.2007.04.006

International Agency for Research on Cancer (IARC). (2020a). Agents Classified by the IARC Monographs, volumes 1-127. https://monographs.iarc.fr/agents-classified-by-the-iarc/ (acessed 15 July 2020)

International Agency for Research on Cancer (IARC). (2020b). Global Cancer Observatory. https://gco.iarc.fr/ (acessed 15 July 2020).

Jaga, K., \& Dharmani, C. (2005). The Epidemiology of Pesticide Exposure and Cancer: A Review. Reviews on Environmental Health, 20(1). doi:10.1515/reveh.2005.20.1.15

Jansson, C., Plato, N., Johansson, A. L.V., Nyren, O., \& Lagergren, J. (2006). Airborne occupational exposures and risk of oesophageal and cardia adenocarcinoma. Occupational and Environmental Medicine, 63(2), 107-112. http://dx.doi.org/10.1136/oem.2005.022467

Kachuri, L., Harris, M. A., MacLeod, J. S., Tjepkema, M., Peters, P. A., \& Demers, P. A. (2017). Cancer risks in a population-based study of 70,570 agricultural workers: results from the Canadian census health and Environment cohort (CanCHEC). BMC cancer, 17(1), 343. https://doi.org/10.1186/s12885017-3346-x

Katzung, B. G., Masters, S. B., \& Trevor, A. J. (2018). Basic \& clinical pharmacology, 14 ed. McGraw-Hill Medical, New York.

Kim, K. H., Kabir, E., \& Jahan, S. A. (2017). Exposure to pesticides and the associated human health effects. Science of the Total Environment, 575, 525-535. https://doi.org/10.1016/j.scitotenv.2016.09.009

Koutros, S., Lynch, C .F., Ma, X., Lee, W. J., Hoppin, J. A., Christensen, C. H., Andreotti, G., Freeman, L .B., Rusiecki, J .A., Hou, L., Sandler, D. P., \& Sandler, D. P. (2009). Heterocyclic aromatic amine pesticide use and human cancer risk: results from the US Agricultural Health Study. International Journal of Cancer, 124(5), 1206-1212. https://doi.org/10.1002/ijc.24020

Kwekkeboom, K. L. (2016). Cancer Symptom Cluster Management. Seminars in Oncology Nursing, 32(4), 373-382. doi:10.1016/j.soncn.2016.08.004

Lee, W. J., Lijinsky, W., Heineman, E. F., \& Markin, R. S., Weisenburger, D. D., Ward, M. H. (2004). Agricultural pesticide use and adenocarcinomas of the stomach and oesophagus. Occupational and environmental medicine, 61(9), 743-749. http://dx.doi.org/10.1136/oem.2003.011858

Lee, W.J., Sandler, D.P., Blair, A., Samanic, C., Cross, A.J., \& Alavanja, M.C. (2007). Pesticide use and colorectal cancer risk in the Agricultural Health Study. International journal of cancer, 121(2), 339-346. https://doi.org/10.1002/ijc.22635

Lee, Y.M., Kim, S.A., Choi, G.S., Park, S.Y., Jeon, S.W., Lee, H.S., Lee, S.J., Heo, S., \& Lee, D.H. (2018). Association of colorectal polyps and cancer with low-dose persistent organic pollutants: A case-control study. PloS one, 13(12), e0208546. https://doi.org/10.1371/journal.pone.0208546

Lerro, C.C., Koutros, S., Andreotti, G., Hines, C. J., Blair, A., Lubin, J., Ma, X., Zhang, Y., \& Beane Freeman, L. E. (2015). Use of acetochlor and cancer incidence in the A gricultural $\mathrm{H}$ ealth S tudy. International journal of cancer, 137(5), 1167-1175. https://doi.org/10.1002/ijc.29416

Liberati, A., Altman, D. G., Tetzlaff, J., Mulrow, C., Gøtzsche, P. C., Ioannidis, J. P., ... \& Moher, D. (2009). The PRISMA statement for reporting systematic reviews and meta-analyses of studies that evaluate health care interventions: explanation and elaboration. Journal of clinical epidemiology, 62(10), e1-e34.

Lo, A. C., Soliman, A.S., El-Ghawalby, N., Abdel-Wahab, M., Fathy, O., Khaled, H.M., Omar, S., Hamilton, S.R., Greenson, J.K., Abbruzzese, J.L. (2007). Lifestyle, occupational, and reproductive factors in relation to pancreatic cancer risk. Pancreas, 35(2), 120-129. doi: 10.1097/mpa.0b013e318053e7d3

Lo, A. C., Soliman, A.S ., Khaled, H. M., Aboelyazid, A., \& Greenson, J.K. (2010). Lifestyle, occupational, and reproductive factors and risk of colorectal cancer. Diseases of the Colon and Rectum, 53(5), 830. doi: 10.1007/DCR .0b013e3181d320b1

Louis, L. M., Lerro, C. C., Friesen, M. C., Andreotti, G., Koutros, S., Sandler, D .P., Blair, A., Robson, M.G., \& Freeman, L.E.B. (2017). A prospective study of cancer risk among Agricultural Health Study farm spouses associated with personal use of organochlorine insecticides. Environmental Health, 16(1), 95. https://doi.org/10.1186/s12940-017-0298-1

McGlynn, K. A., Abnet, C. C., Zhang, M., Sun, X. D., Fan, J. H., O'Brien, T. R., Wei, W.Q., Ortiz-Conde, B.A., Dawsey, S.M., Weber, J.P., Taylor, P.R., Katki, H., Mark, S.D., \& Qiao,Y.L. (2006). Serum concentrations of 1, 1, 1-trichloro-2, 2-bis (p-chlorophenyl) ethane (DDT) and 1, 1-dichloro-2, 2-bis (pchlorophenyl) ethylene (DDE) and risk of primary liver cancer. Journal of the National Cancer Institute, 98(14), 1005-1010. https://doi.org/10.1093/jnci/djj266

Meyer, A., Alexandre, P.C.B., de Rezende Chrisman, J., Markowitz, S.B., Koifman, R.J., \& Koifman, S. (2011). Esophageal cancer among Brazilian agricultural workers: Case-control study based on death certificates. International journal of hygiene and environmental health,214(2), 151-155. https://doi.org/10.1016/j.ijheh.2010.11.002

Mills, P. K., \& Yang, R. C. (2007). Agricultural exposures and gastric cancer risk in Hispanic farm workers in California. Environmental research, 104(2), 282-289. https://doi.org/10.1016/j.envres.2006.11.008 
Modesti, P. A., Reboldi, G., Cappuccio, F. P., Agyemang, C., Remuzzi, G., Rapi, S., ... \& ESH Working Group on CV Risk in Low Resource Settings. (2016). Panethnic differences in blood pressure in Europe: a systematic review and meta-analysis. PloS one, 11(1), e0147601.

Nagtegaal, I. D., Odze, R. D., Klimstra, D., Paradis, V., Rugge, M., Schirmacher, P., Washington, K.M., Carneiro, F., \& Cree, I. A. (2019). The 2019 WHO classification of tumours of the digestive system. Histopathology. https://doi.org/10.1111/his.13975

Pavuk, M., Cerhan, J. R., Lynch, C. F., Schecter, A., Petrik, J., Chovancova, J., \& Kocan, A. (2004). Environmental exposure to PCBs and cancer incidence in eastern Slovakia. Chemosphere, 54(10), 1509-1520. https://doi.org/10.1016/j.chemosphere.2003.10.038

Persson, E. C., Graubard, B. I., Evans, A. A., London, W. T., Weber, J. P., LeBlanc, A., Chen, G., Lin, W., \& McGlynn, K. A. (2012), Dichlorodiphenyltrichloroethane and risk of hepatocellular carcinoma. International journal of cancer, 131(9), 2078-2084. https://doi.org/10.1002/ijc.27459

Peterson, J., Welch, V., Losos, M., \& Tugwell, P. J. O. O. H. R. I. (2011). The Newcastle-Ottawa scale (NOS) for assessing the quality of nonrandomised studies in meta-analyses. Ottawa: Ottawa Hospital Research Institute.

Porru, S., Placidi, D., Carta, A., Gelatti, U., Ribero, M.L., Tagger, A., Boffetta, P., \& Donato, F. (2001). Primary liver cancer and occupation in men: A case-control study in a high-incidence area in northern Italy. International journal of cancer, 94(6), 878-883. https://doi.org/10.1002/ijc.1538

Porth, C., \& Matfin, G. (2009). Pathophysiology: Concepts of altered health states (8th ed.). Philadelphia, PA: Wolters Kluwer Health/Lippincott Williams \& Wilkins.

RStudio Team. (2020). RStudio: Integrated Development for R. RStudio, PBC, Boston, MA URL http://www.rstudio.com/.

Rusiecki, J. A., Hou, L., Lee, W. J., Blair, A., Dosemeci, M., Lubin, J H., Bonner, M., Samanic, C., Hoppin, J.A., Sandler, D .P., \& Alavanja, M. C. (2006). Cancer incidence among pesticide applicators exposed to metolachlor in the Agricultural Health Study. International journal of cancer, 118(12), $3118-3123$. https://doi.org/10.1002/ijc. 21758

Safi, J.M. (2002). Association between chronic exposure to pesticides and recorded cases of human malignancy in Gaza Governorates (1990-1999). Science of the total environment, 284(1-3), 75-84. https://doi.org/10.1016/S0048-9697(01)00868-3

Santibañez, M., Vioque, J., Alguacil, J., De La Hera, M. G., Moreno-Osset, E., Carrato, A., Porta, M., \& Kauppinen, T. (2010). Occupational exposures and risk of pancreatic cancer. European journal of epidemiology, 25(10), 721-730. DOI 10.1007/s10654-010-9490-0

Santibañez, M., Alguacil, J., de la Hera, M. G., Navarrete-Muñoz, E. M., Llorca, J., Aragonés, N., Kauppinen, T., \& Vioque, J. (2012). Occupational exposures and risk of stomach cancer by histological type. Occupational and Environmental Medicine, 69(4), 268-275. http://dx.doi.org/10.1136/oemed-2011100071

Semren, T. Ž., Žunec, S., \& Pizent, A. (2018). Oxidative stress in triazine pesticide toxicity: a review of the main biomarker findings. Archives of Industrial Hygiene and Toxicology, 69(2), 109-125. doi:10.2478/aiht-2018-69-3118

Silver, S. R., Bertke, S. J., Hines, C. J., Alavanja, M. C., Hoppin, J. A., Lubin, J. H., Rusiecki, J. A., Sandler, D. P., \& Beane Freeman, L.E. (2015). Cancer incidence and metolachlor use in the $\mathrm{A}$ gricultural $\mathrm{H}$ ealth $\mathrm{S}$ tudy: An update. International Journal of Cancer, 137(11), 2630-2643. https://doi.org/10.1002/ijc. 29621

Stang, A. (2010). Critical evaluation of the Newcastle-Ottawa scale for the assessment of the quality of nonrandomized studies in meta-analyses. European Journal of Epidemiology, 25(9), 603-605. doi:10.1007/s10654-010-9491-z

Sterne, J. A., Hernán, M. A., Reeves, B. C., Savović, J., Berkman, N. D., Viswanathan, M., ... \& Carpenter, J. R. (2016). ROBINS-I: a tool for assessing risk of bias in non-randomised studies of interventions. bmj, 355.

U.S. Environmental Protection Agency (USEPA). (2013). Chronic Effects, in: Recognition and Management of Pesticide Poisonings., 6 ed. https://www.epa.gov/sites/production/files/2015-01/documents/rmpp_6thed_final_lowresopt.pdf (acessed 17 July 2020).

VoPham, T., Brooks, M.M., Yuan, J.M., Talbott, E.O., Ruddell, D., Hart, J.E., Chang, C.C.H., \& Weissfeld, J.L. (2015). Pesticide exposure and hepatocellular carcinoma risk: A case-control study using a geographic information system (GIS) to link SEER-Medicare and California pesticide data. Environmental research, 143, 68-82. https://doi.org/10.1016/j.envres.2015.09.027

VoPham, T., Bertrand, K. A., Hart, J. E., Laden, F., Brooks, M. M., Yuan, J. M., Talbott, E. O., Ruddell, D., Chang, C. H., \& Weissfeld, J. L. (2017). Pesticide exposure and liver cancer: a review. Cancer causes \& control : CCC, 28(3), 177-190. https://doi.org/10.1007/s10552-017-0854-6

Wang, Y., Lewis-Michl, E. L., Hwang, S.A., Fitzgerald, E. F., \& Stark, A.D. (2002). Cancer incidence among a cohort of female farm residents in New York State. Archives of Environmental Health: An International Journal, 57(6), 561-567. https://doi.org/10.1080/00039890209602089

Yadav, I. C., \& Devi, N. L. (2017). Pesticides classification and its impact on human and environment. Environmental Science and Engineering, 6, 140-158.

Zani, C., Toninelli, G., Filisetti, B., \& Donato, F. (2013). Polychlorinated Biphenyls and Cancer: An Epidemiological Assessment. Journal of Environmental Science and Health, Part C, 31(2), 99-144. doi:10.1080/10590501.2013.782174

Zhao, B., Shen, H., Liu, F., Liu, S., Niu, J., Guo, F., \& Sun, X. (2012). Exposure to organochlorine pesticides is an independent risk factor of hepatocellular carcinoma: a case-control study. Journal of exposure science \& environmental epidemiol 